\title{
Style and meaning in translations of the Qur'anic verb-noun collocations into English
}

\author{
Mutahar Qassem \\ Najran University, Najran, Saudi Arabia
}

\begin{abstract}
Purpose - This paper aims to investigate seven prominent translations of the Qur'anic verb-noun collocations into English (Pickthall, 1930; AL-Hilali and Khan, 1977; Ali, 1934; Arberry, 1955; Shakir, 1999; Sarwar, 1981; Saheeh International, 1997) to unfold their renditions of the style and meaning of such Qur'anic verb-noun collocation into English.

Design/methodology/approach - The study follows a corpus-based research in a sense that the study is conducted on seven translations of the Noble Qur'an that have been taken form The Qur'anic Arabic Corpus, using linguistic and exegetical analyses. Based on Reiss' model of text analysis (2000), the author analyses the intralinguistic and extralinguistic features of the Qur'anic verb-noun collocations.

Findings - Findings reveal that linguistic and exegetical analyses are perquisites for adequate rendition, which prevent deviation in meaning and translation loss. It is also found that Qur'anic collocations use unique literary techniques and devices, which hinder their natural and adequate renditions into English.

Originality/value - The novelty of this study lies in studying the architectural design of the Qur'anic verb-noun collocations in terms of the unique selection of words and style. Such unique architectural design of such collocations creates monumental hindrances in their rendition into other languages, which have not been given due attention in translation studies.
\end{abstract}

Keywords Style, Translation, Meaning, Verb-noun collocation, The Qur'an

Paper type Research paper

\section{Introduction}

Collocations play an efficient role in effective use of languages whose use reflects a natural use of a language. Besides, they have a cohesive function and generate a special meaning that is different from the meaning of its constituent parts (Izwaini, 2016). Knowledge of collocation is crucial for a translator in both the source language (SL) and target language (TL) as it enables translators to convey the stylistic features of the SL text to TL readership. Newmark (1988, p. 125) compares between text and human body, "likens grammar to skeleton, words to flesh and collocation to tendons that connect them to one another". The role of collocation in translation lies in communicating the message of the source text (ST) to the TL readers effectively, having the same effect on the TL readership as it does the ST on the SL readership (Ghazala, 2008). Newmark (1988, p. 180) sates that the translator:

(C) Mutahar Qassem. Published in PSU Research Review. Published by Emerald Publishing Limited. This article is published under the Creative Commons Attribution (CC BY 4.0) licence. Anyone may reproduce, distribute, translate and create derivative works of this article (for both commercial and non-commercial purposes), subject to full attribution to the original publication and authors. The full terms of this licence maybe seen at http://creativecommons.org/licences/by/4.0/legalcode

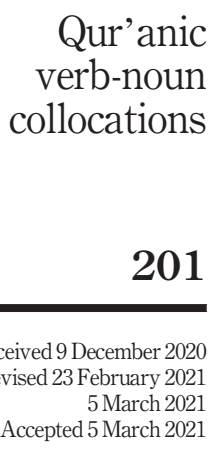

Received 9 December 2020 Revised 23 February 2021 Accepted 5 March 2021 
PRR

5,3

[...] will be 'caught' every time, not by his grammar, which is probably suspiciously 'better' than an educated native's, not by his vocabulary, which may well be wider, but by his unacceptable or improbable collocations.

Therefore, adhering to the collocational conventions of the target language means achieving naturalness of the translation (i.e. idiomaticity and nativelikeness) (Newmark, 1988).

Translation of collocations in the Noble Qur'an is more problematic than translation of collocations in other types of genre due to the special context of the Qur'an and its unique linguistic features (Abdul-Raof, 2018). The Noble Qur'an uses unique literary techniques and stylistic features in conveying its message, making its translation well-nigh impossible (Qassem, 2020; Allaithy, 2020; Mir, 1988; Sadiq, 2008; Abdul-Raof, 2004). Research on translation of the Qur'anic collocations does not receive due attention in translation studies; hence, this study is dedicated to the study of the prominent of translations of verb-noun collocations in the light of linguistic and exegetical knowledge of the Noble Qur'an. To the best of the author's knowledge, only sparse studies on this area of research exit (Alshajea, 2014; Dweik and Abu Shakra, 2011; Bahumaid, 2006; Ghazala, 2004, 2008; Alrabiah et al., 2014; Obeidat et al., 2020; Hassan and Menacere, 2020). However, the focus of these studies was on the problems and the procedures of translating collocation rather than offering linguistic and exegetical analyses of the translations of collocations. The novelty in this study lies in studying linguistically and exegetically the prominent translations of the verb noun-collocations of the Noble Qur'an into English to reveal the extent translators are successful in conveying the style and meaning of the verb-noun collocations to TL readers.

\section{Literature review}

Collocation is one of the semantic features, namely a phraseological level (Farghal and Almanna, 2015). It is a result of arbitrary relation between the node and the collocate. This relation between the node and the collocate forms a regular pattern, which is "a characteristic of the lexical profile of a language" (Crystal and Davy, 1969, p. 56). Stubbs (2002, p. 225) defines collocations as "semantic relations between the node and collocates." He (2001b, p. 14) adds that collocations are "combinations of words in phrases are [...] a good candidate for the basic unit of language in use. Collocations are also defined as "the habitual -co-occurrence of individual lexical items" (Crystal, 1991 cited in Newmark, 1988). Ghazala (1995, p. 106) defines collocations as "a combination of two or more words that always occur together consistently in different texts and contexts in languages". Martyńska (2004, p. 2) states that the term "collocation" has its origin in the Latin verb "collocare" which means to set to arrange. Based on such definitions, collocations could be defined as formulaic expressions that have a regular pattern and do not change in different contexts.

Linguists classify collocations according to their word order into different types. The most common types are:

- Adjective + noun: flawless argument, net weight, immaculate performance, etc.;

- Noun+ noun: Brain drain, death sentence, status quo;

- Verb+ noun: deliver a verdict, attend a lecture, exert an effort, pass a law, deliver news, etc.; and

- Adjective + adjective: hale and hearty, alive and kicking, well and good, etc.

Hausmann (1989, p. 1010), for example, divides collocations into six types:

(1) adjective + noun (heavy smoker);

(2) (subject-)noun + verb (storm - rage); 
(3) noun + noun (piece of advice);

(4) adverb + adjective (deeply disappointed);

(5) verb + adverb (severely criticize); and

Qur'anic verb-noun

(6) verb + (object-)noun (stand a chance).

\section{Translation procedures}

Translation procedures are linguistic decisions used in solving a translation problem, which may take different forms depending on the aim of translation techniques: translation of the sense, linguistic transcodification, modification of semiotic and communicative categories and philological (academic or critical translation) (Hurtado Albir and Alves, 2009). Olk (2013) classifies translation procedures into "transference", "transference + explicitation", "transference + explanation", "neutral explanation", "omission" and "cultural substitution". Ghazala (2008) classifies translation procedures, drawing on Nida (1988) into cultural equivalent, cultural correspondence, accepted translation, naturalisation, general sense, transcription, etc.

In translating the Noble Qur'an, the translator should choose a translation procedure that prevents abandonment of semantic deviation (wrong denotative meaning), overtranslation (giving more details than its corresponding TL unit) and "undertranslation" (giving less detail and is more general than the original (Newmark, 1988, pp. 284-5). Olk (2013) argues that explicitation and explanation strategies are one of the most important strategies in translating cultural signs. Mailhac (1977) argues that context guides the translator in detecting the meaning of words, phrases and sentences in a text. The translator should consider the context when searching for the meaning of SL words in dictionaries and producing the SL meaning into the TL. Recognizing the context enables the translator to identify the areas that entail explanation, omission, explicitation and cultural equivalent, thereby making the right decisions. He adds that that the less informed the reader, the greater the amount of information required.

Katan (2012) argues that in spite of the effort Eugene Nida put in allowing readers to read and respond to the Bible in translation in the way the gospel writers had originally intended, Nida said "Reader response can never be identical to the original due to different historical, cultural and environmental contexts" (1964, p. 159). Accordingly, Katan (2012) suggested that the translator should try to reduce the difference between the SL and TL through use of appropriate translation procedures.

Reiss (2000) determines the main functions of texts (i.e. informative, expressive and operative texts). These three functions should be considered by translators in the rendition process. Informative texts require explicit statements, while expressive texts necessitate adherence to the SL author perspective, and aesthetics should be considered during rendition. Further, operative texts require an appropriate translation according to the way the intended audience is assumed to respond to the text. According to EL-Zeiny (2011), the translator should adhere to the informative level in translating the Noble Qur'an at the expense of other levels (i.e. expressive and aesthetic). The main function of the Qur'anic text is to inform (teach and preach), though it is a linguistic miracle. One may ask: What about the linguistic features of the Qur'an? Translators should consider these linguistic features in their translation as they carry meaning and stylistic effect. If these linguistic features are untranslatable, translators should deliver the meanings the linguistic features carry (Qassem, 2020). 
PRR

5,3

204
The Noble Qur'an employs a unique use of collocation in the selection of lexis, figure of speech and novel composition, which creates barriers before translators in the process of comprehension and re-production. Accordingly, this study aims to investigate the problematic areas that are encountered in the seven current translations of the Noble Qur'an verb-noun collocations (i.e. Pickthall, 1930; AL-Hilali, and Khan, 1977; Ali 1934; Arberry, 1955; Shakir, 1999; Sarwar, 1981; Saheeh International, 1997) into English and the translation procedures used by translators to overcome such problematic areas. Besides, the study is devoted to reveal to what extent translation procedures used by translators are successful in delivering the meaning and stylistic features of the collocations of the Noble Qur'an into English. The Qur'anic text is rich in its vocabulary, morphology and syntactic structures. Its language is unique in its eloquence and style, which differentiate it from any other classical Arabic texts.

Obeidat et al. (2020) provided a new fairly detailed analysis of the features and classifications of the Qur'anic collocations. They found that collocations can be classified semantically into acts of worship collocations, divine collocations and rhetorical collocations. Each group of those collocations has its syntactic patterns that should be studied deeply. Hassan and Menacere (2020) examined a sample of the Qur'anic collocations focusing on five selected English translations of the Qur'an to assess the degree of faithfulness and accuracy and to find out whether the final product is coherent, consistent, error-free, easier to read and understand. The findings showed that the translation of the Qur'an in English is still a work in progress, and it needs to be periodically evaluated and updated to reflect feedback provided from different perspectives and regions of the world. Ali (2020) compared and evaluated the strategies adopted by the authors of three English translations of the Qur'an, translating lexical items, metaphors and metonymic words. The study revealed that the translators faced difficulties in rendering the sample of lexical items into English, and recommended that future translators should be aware of the unique qualities of the Qur'an's classical Arabic and avoid using a literal translation method to convey its message informatively to the target audience.

\section{Literature review and research questions}

Scrutinizing literature on translation of the Qur'anic collocations revealed that linguistic and exegetical analyses of the Qur'anic collocations in general and verb-noun Qur'anic collocations in particular were not given due attention in translation studies. Therefore, this study aims to bridge the gap through answering the following research questions:

RQ1. To what extent do the targeted translations of the Noble Qur'an successfully render the meaning and style of the Qur'anic verb-noun collocations into English?

RQ2. What are the procedures translators use in their translation of the Qur'anic verbnoun collocations into English?

RQ3. What are the challenges that hinder the translation of the Qur'anic verb-noun collocations into English?

\section{Methods}

The study followed a corpus-based approach in a sense that the data of the study were taken from The Qur'anic Arabic Corpus, which includes major works in translations of the Noble Qur' an (A1- Hilali and Khan, 1977; Ali, 1934; Arberry, 1955; Pickthall, 1930; Sahih International, 1997; Sarwar, 1981; Shakir, 1999). The verb-noun collocations are the target of 
the study in these seven translations, which were analyzed qualitatively in terms of contextbased and linguistic exegeses of the Qur'an and Reiss' model of text analysis. The author drew upon Reiss' model (2000) of text analysis, which is based on the Skopos theory. Reiss (2000, pp. 48-88) listed a series of intralinguistic and extralinguistic instruction criteria (instruction by which the adequacy of a TT may be assessed). This model helps study the translation of verb collocations of the Noble Qur'an. The Qur'anic collocations were analyzed in terms of linguistic criteria (linguistic components: semantic equivalence, lexical equivalence, grammatical and stylistic features) and non-linguistic factors (situation, subject field or domain time place, culture, receiver, sender and affective implications). This analysis was achieved through employment of contextual and linguistic analysis, drawing on the following context and linguistic based- exegeses (Ibn Mandhur, 1883; Al-Alousi, 2000; AlZamakhshary; AL-Alousi, 2000; AL-Asfahany; Al-Thaalby; Ibn Kathir, 2009; Al-Tabari, 1981). The contextual exegeses analysis showed the context of the Noble Qur'anic collocations, whereas the linguistic-based exegeses showed the linguistic and stylistic features of the collocations. In doing so, translations of the Noble Qur'an were compared with such exegetical and linguistic analyses to reveal the extent the translations were successful in their renditions.

\section{Translators targeted by the study}

This section introduces the targeted translators of Noble Qur'an in terms of their linguistic and religious background and the translation approaches they follow, which may shape the product of translation:

- Muhamed Pickthall (1930) is the first translation of the Qur'an by a Muslim (converted) whose first language is English. His translation is one of the widely used English translations, which faithfully represents the sense of the original (Nassimi, 2008). Pickthall seems to adopt a literal translation method and this approach may sometimes risk distorting the implicit meanings in the Qur'an and misleading the target reader (Ali, 2020).

- Abdullah Yusuf Ali (1934) is not a native speaker of English. His translation shows stylistic quality, accuracy and naturalness, that has abundant notes, reflecting Yusuf Ali's vast learning (Aldahesh, 2016b; Nassimi, 2008). He declares that all the levels of meaning are important and should be reproduced in the TL. He states that when sacrificing any of these levels is obligatory, he compensates for the loss by adding rhyme and rhythm to the text as well as prefacing the Surahs with introductions and glossing it with footnotes (El-Zeiny, 2011). Al-Khatị̂b (2010 cited in Ali, 2020) criticized Ali's adoption of semantic and literal approaches, which ignores the target reader, who needs communicative translation to understand the message of the sacred text. He adds that Ali also adopts a literal translation technique at times, using footnotes to clarify the original text and a translation style that seems "overly poetic" and "romantic".

- Shakir's The Holy Qur'an (1999) is one of the famous English translations, which uses clear and modern English and does not contain any notes. He is a native speaker of neither Arabic nor English. The translator's name is Mahomedali Habib with a pen name of Shakir. According to both Kidwai's and Clay Smith reviews, this translation is mostly copied from Muhammad Ali Lahori's English translation Qur'an (Nassimi, 2008).

- Arberry (1955) is a non-Muslim scholar. He is an English native speaker. He aspires to give, relatively, maximum equivalence at the expressive and aesthetic levels 
PRR

5,3

206

because he wants to echo the music and rhetorical grandeur of the original (Aldahesh, 2016b). He attempts to give maximum equivalence at the informative and vocative levels of meaning, trying to sound comprehensible to the TL reader (El-Zeiny, 2011). His translation is considered as a fair and authentic work by many Muslim scholars (Nassimi, 2008).

- AL-Hilali and Khan (1977) is one of the most widely used translation that devote ample attention to the informative level of meanings, saving no effort to echo all the other levels of meaning, when no conflict exists (El-Zeiny, 2011). He relies on exegetical knowledge to attain clarity of meaning through glosses and notes. It is translated by Muhammad Taqī-ud-Dīn Al-Hilali (is a Moroccan scholar) and Muhammad Muhsin Khan is a Pakistani scholar. This translation is intended to 'present the meanings of the Qur'an in the way the early Muslims had known it (Nassimi, 2008). Nevertheless, the use of these techniques can tend towards overtranslation, meaning that the target reader receives too much information, which may prove a hindrance to their understanding of the text (Ali, 2020).

- Sahih International (1977) is based on translation of AL-Hilali and Khan, but with the following two improvements: the language has been significantly simplified and clarified, and footnotes have been added to replace the parenthesis within the text. The initial print of this translation had Umm Mohammad as its translator, but the later ones do not have a translator name (Nassimi, 2008). It has been translated by three American women: Aminah Assami, Amatullah J. Bantley, Mary Kenndy (Wikipedia).

- Sheikh Mohammad Sarwar (1981) shows explanatory translation and a clear style, without any additional notes and introduction. He is a Pakistani-born American Islamic scholar, specializing in Islamic theology and philosophy. He is also known as the first representative of the late Ayatollah Abul-Qasim al-Khoei to the Shia Muslims of North America (Aldahesh, 2016b; Nassimi, 2008).

\section{Data analysis}

Based on Reiss' model of text analysis (2000), the author followed three levels of analyses (i.e. contextual, linguistic and translation analyses). The linguistic analysis is based on linguistic based-exegeses and linguists' analysis of the selected verb-noun collocations (Ibn Mandhur, 1883; Al-Alousi, 2000; Al-Zamakhshary; AL-Alousi, 2000; AL-Asfahany; Al-Thaalby). The contextual analysis is based on context-based exegeses (Ibn Kathir, 2009; Al-Tabari, 1981) and linguistic-based exegeses, as they interpret verses of the Qur'an linguistically and contextually. The translation analysis studies the translations of the selected verb-noun collocations in the Noble Qur'an in terms of linguistic and the exegetical analyses of those collocations to reveal the extent the translations consider the meaning and style of the selected verb-noun collocations. Below is a detailed analysis of the targeted verbnoun collocations, which includes five verb-noun collocations.

1. 1ال تعالى (الآن حصحص الحق12:51) The collocation takes the structure of a verb-noun collocation, which has been mentioned twenty-one times in the Noble Qur'an and occurred frequently in Arabic poetry (ALHussaini, 2007). The collocation was mentioned in Yousuf Surah (12:51). Ibn Mandhur (1883) argues that the verb 'حصحص' has several meanings, including the intensity of the speed, the cold day without clouds, the movement in something until it settles, stirring and flipping 
something. He adds when it is collocated with ' الحق', it means statement of the truth after concealment. Al-Alousi (2000) said that the collocation ' حصحص الحق' means that the truth is revealed after concealment. He adds that it is taken from the share, meaning that there is a share for the truth and a share for falsehood and in this verse, it is the share of the truth. AlZamakhshary (1934) said that the collocation ' حصحص الحق' means that the truth was established and settled. He mentions the context of the collocation saying that the collocation is said by the wife of AL-Azeez when she is confessed the guilt of seducing the Prophet Joseph, admitting the innocence and integrity of Joseph (It was I who tried to seduce Joseph). AL-Andalusi (2002) argues that the collocation means the it is the turn of the truth to appear and the falsehood to be refuted.

The translations revealed that all translators adopt an explicitation procedure to get the meaning clear for TL readership, meaning they adhere to the informative level of meaning. Some translators use addition procedures (manifest to all, at last discovered), trying to covey the connotation of the Qur'anic collocation as in Yusuf Ali (1934), Shakir (1999) and AL-Hilali and Khan (1977). Arberry (1955) neutralizes the Qur'anic collocation, translating collocation freely. All Translators could not consider the style of the collocation due to the unique selection of the node حصحص, which may not have an equivalent in English (Table 1).

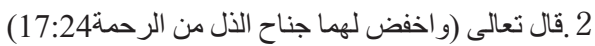
The node of the collocation 'اخفض'denotes different meanings in Arabic, but when it is collocated with 'جناح', it indicates modesty and kindness (AL-Alousi, 2000). It is a metaphor that resembles obedience to parents like lowering of bird's wing, because if the bird wants to fly, it spreads its wings and raises them to fly higher and if they want to land, they lower their wings (Al-Zamakhshary, 1934). It is a figure of speech in which modesty and kindness are likened to the wing of the bird when it is folded. Al-Alousi (2000) added that the collocation indicates showing humility to parents. The collocation become a proverb in Arabic to indicate modesty and kindness (Ibn Ashoor, 1997 cited in AL-Hussaini, 2007). It is a hyperbole in humiliation to parents (out of mercy) to show one's excessive mercy and compassion for parents, because of their aging and their lack today for those who were weak and poor in their childhood (Al-Zamakhshary, 1934).

Most translators used the SL metaphor in their translation of the Qur'anic collocation "lower wing", which may not have stylistic effect on TL readers as it does on SL readers. The translators adhere to the structure of the Qur' anic collocation, but it may confuse the TL readers. The translators use strategy of addition to make the meaning explicit to TL readers. However, adding a metaphorical expression "lower the wing" may confuse the TL readers. Shakir (1999) and Sarwar's translations deliver the meaning of the Qur' anic collocation, deleting the metaphor to ensure the clarity and smoothness of the translation. In all cases of translations, the stylistic effect of the Qur'anic collocation is not delivered to TL readers (Table 2).

\begin{tabular}{lll}
\hline & & \\
Translator & The translations \\
\hline Sahih International (1977) & The truth has become evident \\
Pickthall (1930) & Now the truth is out & \\
Yusuf Ali (1934) & The truth manifest (to all) \\
Shakir (1999) & The truth manifest (to all) \\
Muhammad Sarwar (1981) & The truth has come to light \\
Mohsin AL-Hilali\& Khan (1977) & Now the truth is manifest (to all) & Table 1. \\
Arberry (1955) & 'Now the truth is at last discovered & Tase \\
\hline
\end{tabular}




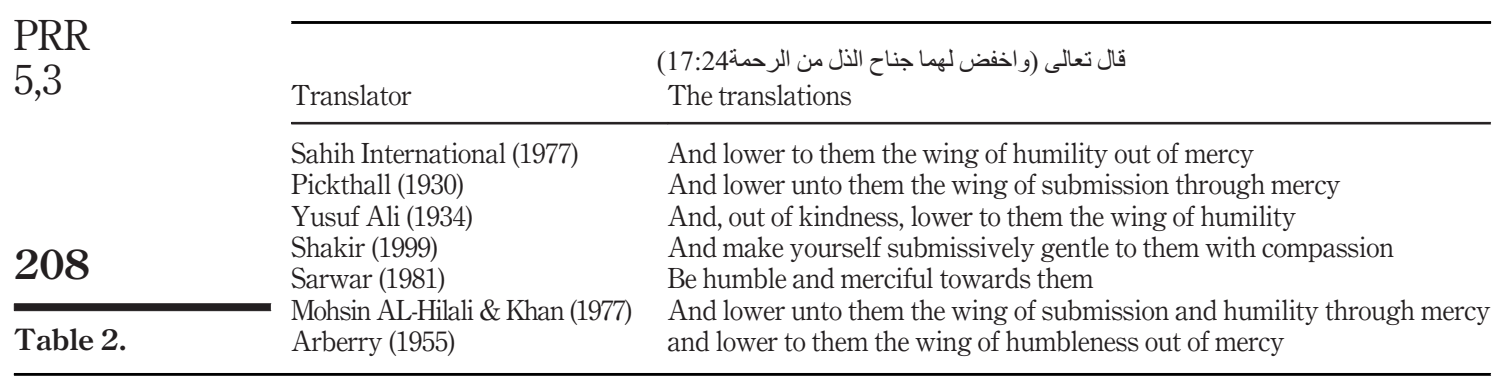

3. قال تعالى (وليربط على قلوبهم: الانفال (8) 11 : The node of the collocation 'يربط'denotes persistence and steadiness. When it is collocated with ' قلوبهن', it means to make one's hearts strong and firm. AL-Asfahany (1992) said that ' 'ربط على قلبه ' means granting him or her patience and strength. It has been mentioned three times in the Noble Qur'an (AL-Hussaini, 2007). AL-Hussaini (2007) argues that it is a metaphor that stand for steadiness and removal of nervousness. Al-Zamakhsahry (1934) argues that the meaning of the collocation is to strengthen believers through granting them patience and encouragement to say the truth. Ibn Ashoor (1997 cited in AL-Hussaini, 2007) argues that collocating between the noun 'قلوبكم' and the verb' ربط '19 a metaphor for strength of the belief and absence of hesitation. Al-Alousi (2000) said that the collocation means to bind their hearts together, that is, to strengthen them with confidence, by the kindness of God Almighty. Al-Wahidi (cited in Al-Alousi, 2000) said that the collocation means to make the believers patient, not fleeing during the battle. Al-Thaalaby (1977) said that 'بربط على قلوبهر' means victory and certainty through linking their heart with patience. Ibn Kathir (2009) said that the collocation means to strengthen ones' hearts with patience and to encourage them to fight the enemies, and this is the inner courage.

Examining the translations revealed that the translators adhere to the informative level through explaining the metaphorical collocation though using "steadfast and strengthen". Shakir (1999) used the metaphorical expression "fortify your heart", which may not show the SL image, but it has effect on TL readers as it does exist in Gospel of Matthew [1]. It can be said here all the translators could not deliver the stylistic effect of the metaphorical Qur'anic collocation because of the unique metaphorical construction of the Qur'anic collocation. There is a need to rethink of the style of the Qur'anic collocation in terms of the selection of words and style in conveying the Qur'anic collocation to TL reader (Table 3).

Translator

Sahih International (1977)

Pickthall (1930)

Yusuf Ali (1934)

Shakir (1999)

Sarwar (1981)

AL-Hilali\& Khan (1977)

Table 3.
قال تعالى (وليربط على قلوبهم: الانفال 11 :8)

The translation

To make steadfast your hearts To make steadfast your hearts To strengthen your hearts He might fortify your hearts Strengthen your hearts And to strengthen your hearts And to strengthen your hearts 
4. 4 (نقال تعالى (نكص على عقبيه (8:48) The node of the collocation 'نكص ' means "flinch", "move to the back" and turned a way (AL-Maany Dictionary [2]). The collocate 'عقبيه ' means "heels". Ibn Mandhur(1983) said that ' ' means refraining from something, adding that the whole collocation means refraining from doing the good. Ibn Ashoor (1997 cited in AL-Hussaini, 2007) argues that the collocation means to return from where he or she came from, meaning fleeing. He added that reason behind collcating between 'عقبيه ' نكص', is that "fleeting" occurs by heels. Al-Alousi (2000) said that the collocation means to turn back on his or her heels (i.e. he ran away or returned to retreat). He added the word ' عقب ' mean back of the foot. This exprssion connotes abdomination of the act) Al-Hissaini, 2007). Ibn Kathir (2008) explains the context of the verse, saying that the collocation occurs when Statan ran away in the battle with the Prophet Mohammad peace be upon him and his companons. AL-Andalusi (2002) said that ' 'نكص ' means in the Language of Saleem flee, run away and expel.

As for the translations, four translators (Sahih International, 1997; Yusuf Ali, 1934; Shakir, 1999; Arberry, 1955) rendered the collocation with its Qur'anic metaphor. AL-Hilali and Khan (1977) and Pickthall (1930) neutralize the Qur'anic collocation, translating them as "ran away" and "took flight", respectively. Sarwar (1981) translates the collocation freely without considering the form of the SL collocation (Table 4).

5.قال تعالى (ألم نشر ح للك صدرك

The node of the collocation ' شرح ' means to open and the collocate' صدرك ' means "breast". The literal meaning of the collocations means to open your breast, which may mean something else for TL readers. Al-Thaalaby (1977) argues that the meaning of the ' الثر ح the opening of what prevents the Prophet Muhammad from perception and realization. It means God Almighty opened the chest of his Prophet for guidance, and knowledge by dismissing the concerns that prevent him from realizing the truth. He added that opening the heart means expanding, and softening it with faith, sermons, knowledge, prophethood and wisdom. AL-Zamkhsahary (1934) said that the collocation means expanding a heart so that it can deal with the concerns of prophethood and the call of the human kind and jinn to Islam. He added that expanding your heart with the knowledge and wisdom, and we make your breast free from the distress and embarrassment that comes with blindness and ignorance. Al-Tabari (1981) said that the collocation means expanding your heart for guidance and faith in God and knowledge of the truth so that it can be an area for wisdom. Ibn Kathir (2009) said that the collocation means enlightening the chest, making it spacious, vast, wide and easy, containing no difficulty, hardship or burden. Many commentators explained the collocation "chest” as heart such as Al-Thaalaby (1977), Al-Tabari (1981) and AL-Zamkhsahary (1934) which is selected by Sarwar (1981) translation.

\begin{tabular}{ll} 
& \\
Translator & The translation \\
\hline Sahih International (1977) & He turned on his heels \\
Pickthall (1930) & He took flight \\
Yusuf Ali (193 & He turned on his heels \\
Shakir (1999) & He turned upon his heels \\
Muhammad Sarwar (1981) & Then Satan betrayed his friends \\
Mohsin AL-Hilali\& Khan (1977) & He ran away \\
Arberry (1955) & Withdrew upon his heels
\end{tabular}

Qur'anic verb-noun collocations

209 
PRR

5,3

All translations were literal, except Muhammad Sarwar (1981) who translated the collocation as "comfort your heart", which may deliver a part of meaning. The translations may not be clear for TL readers. Comparing the translations with the contextual and linguistic exegeses showed that the translators did not adhere to the informative level. Comparing their translations with the linguistic and exegetical analyses revealed that the stylistic effect of the Qur'anic collocation is not rendered into TT and their translations are short of expressing the Qur'anic collocation, which is due to unique selection of the node ' نشرح', which may not be lexicalized into English (Table 5).

\section{Discussion of results}

Analyses of the translations of some verses of the Noble Qur'an into English revealed hindrances in translating the verb-noun collocations in terms of style and meaning. If rendering the style is unfeasible, then meaning can be rendered into the TL through integrated exegetical and linguistic analyses and appropriate use of translation procedures. The following is a discussion of the findings of the study.

\section{Untranslatability of the style of the noun-verb collocations and the relative possibility of rendering their meanings}

The Noble Qur'an uses a unique use of collocation in the selection of lexis, figure of speech and novel composition, which creates barriers before translators in the process of comprehension and re-production. The translators have two options: rendering the style or the meaning. It is noticed that some translators sacrifice the meaning at the expense of the style. The translators follow literal translation to ensure economic use of language and show the structure of the Qur'anic collocation, which results in general translation. As I see it, when there is a conflict between the informative and aesthetic level of meaning, informative meaning should be preferred. (Baker, 2011; EL-Zeiny, 2011; Newmark, 1966). In this regard, Nida (1964) argues that due to different historical, cultural and environmental contexts between the SL and TL, TL readers' responses are not identical to the original. Accordingly, Katan (2012) suggested that the translator should try to reduce the difference between the SL and the use of appropriate translation procedures. Based on the data of the study, the current translations deliver a part of meaning of the verb-noun-collocations. Therefore, there is a need for improvement of the quality of the current translations of the verb-noun collocations.

\section{Translators' approach and the translations of the collocations}

Based on analysing the data, most translators do not adhere to the informative functions in their translation of some verb-noun collocations, which might be due to their attempt to consider the structure of the SL collocations. The studies conducted on approaches followed

Translator

Sahih International (1977)

Pickthall (1930)

Yusuf Ali (1934)

Shakir (1999)

Sarwar (1981)

Mohsin AL-Hilali\& Khan (1977)

Arberry (1955)

$$
\text { فال تعالى (ألم نشرح للك صدرك 94:1) }
$$

The translation

Did We not expand for you, [O Muhammad], your breast? Have We not caused thy bosom to dilate? Have We not expanded thee thy breast? Have We not expanded for you your breast have We not comforted your heart? Have We not opened your breast for you Did We not expand thy breast for thee? 
by translators may not be accurate given that their findings are based on their targeted data. Some studies reported that Ali (1934) considered all levels of meaning (El-Zeiny, 2011). Conversely, Al-Khatīb (2010) criticized Ali's translation of the Qur'an in his adoption of semantic and literal approaches. Al-Khatib believes that the semantic approach ignores the target reader. As for AL-Hilali and Khan (1977), their translation was described as paying ample attention to the informative level of meanings (El-Zeiny, 2011). They rely on exegetical knowledge to attain clarity of meaning through glosses and notes. Nevertheless, the use of these techniques can tend towards over-translation, meaning the target reader receives too much information, which may prove a hindrance to their understanding of the text (Ali, 2020). In their translation of some verb-noun collocations, they adhere to the stylistic level of meaning. These opposing opinions on the translations demonstrated that the findings of the studies on assessment of the current translation cannot be generalized. Therefore, comprehensive studies are required to investigate the approaches followed by translators.

\section{Use of the Reiss' model (2000)}

Reiss' model (2000) is effective in the analysis of the Qur'anic collocations given that the model analyses both the intralinguistic and extralinguistic features of the text. The model analyses the intralinguistic features in terms of linguistic components: semantic equivalence, lexical equivalence, grammatical and stylistic features) and extra linguistic factors in terms of situation, subject field or domain time place, culture, receiver, sender and affective implications, which help to arrive at full image of the analysed text, sentence, phrase or a word.

\section{Collocation in Noble Qur' an uses literary devices that do not have equivalents in English}

One of the features of Qur'anic verb-noun collocation is the use of metaphor, which do not have their equivalent in English. Some translators render these metaphorical expressions into English, though these metaphors may not have effect on the TL readers as they do on the SL readers. Their translations of the Qur'anic metaphors may confuse TL readers. They may have a point in their employment of literary translation given that TL-oriented method of translation makes the TL reader ignorant of the SL culture (Qassem and Gurindapalli, 2015). Some translation theorists state that a translator struggles between the naturalness and accuracy of meaning, however keeping the linguistic features of the ST in the TT may not be realized by the TL readers since each language has its own way of expression of aesthetic and stylistic features (Baker, 2011; Nida, 1996). The use of collocation in the Noble Qur' an manifests figurative language as in a unique mental and moral climate, distinct style supported by a value-laden idiom (EL-Zeiny, 2011). In this puzzling situation, the translators have two options: whether to render the stylistic features at the expense of meaning or favor the meaning at the expense of stylistic features. In the Qur'anic context, the translator should sacrifice the style at the expense of meaning (Newmark, 1966; Baker, 2011), as the main function of the Qur'anic text is admonition and instruction (Abdul-Raof, 2019).

\section{Employment of both exegetical and linguistic analyses in translation of the Qur' anic collocations}

Both linguistic and exegetical analyses are significant factors in translation process, as they provide the translators with intertextual and extratextual features of the Qur'anic verse. Through linguistic analyses, the translator can identify the intertextual signs and comprehend their denotation and connotation (Gonzalez and Scott-Tennen, 2005). The context and linguistic-based exegeses show translators the context and linguistic feature of the Qur'anic verse (Qassem, 2020). Lack of exegetical analysis may lead to general translation and translation loss, which are manifested in some data of the current study. 
PRR

5,3

\section{Conclusion}

The study analyses linguistically and exegetically some verb-noun Qur'anic collocations into English, which reveals monumental hindrances before rendering the style of Qur'anic collocations into English. However, some translators attempt to render the style of the Qur'anic collocations, they sacrifice the informative function of the noun-verb collocation. Communicative translation could be the right solution in case of conflict between the style and meaning. The current translations of the verb-noun collocations into English show that they adhere to the informative level of meaning, though they render only parts of the meaning of the Qur'anic collocations into English. Employment of integrated linguistic analysis and context and linguistic exegeses help in unveiling the linguistic and contextual features of the text, which simplify a translator's task in choosing the right translation procedure that consider the style and meaning of the Qur'anic collocations.

\section{Notes}

1. Fortify Your Hearts to Be Witnesses (Matthew 27:32 - 28:15; Luke 24:8-53)

2. www.almaany.com/en/dict

\section{References}

Abdul-Raof, H. (2004), "The Qur'an: limits of translatability”, in Faiq, S. (Ed.), Cultural Encounters in Translation from Arabic, Multilingual Matters Ltd., Clevedon, pp. 91-106.

Abdul-Raof, H. (2018), New Horizons in Qur'anic Linguistics, Routledge, London.

Abdul-Raof, H. (2019), Text Linguistics of Qur'anic Discourse, Routledge, London.

Al-Alousi, M. (2000), Ruh al-Ma'ani, Dar Ihya Turath Al-Arabi, Beirut, Lebanon.

Al-Andalusi, A. (2002), Al-Bahr Al-Muheet, Dar Ihya Turath Al-Arabi, Beirut, Lebanon.

Aldahesh, A. (2016b), "Towards a model for analyzing and assessing translation of Qur' anic idiomatic phrasal verbs", Arab World Journal, Special Issue on Translation, No. 5, pp. 33-53.

Ali, A. (2020), "Lexical and semantic problems in translating the Qur'an: a comparative study", TRANSLATOLOGIA, Vol. 1, pp. 52-86.

Al-Khațīb, A. (2010), “Abdullah Yusuf Ali: a study of his life and translation”, Journal of Qur'anic Studies, Vol. 11 No. 1, pp. 169-198, doi: 10.3366/E1465359109000692.

Alrabiah, M., Alhelewh, N., Al-Salman. and Atwell, E. (2014), "An empirical study on the Holy Qur'an based on a large classical Arabic corpus", International Journal of Computational Linguistics (IJCL), Vol. 5 No. 1, pp. 1-13.

Alshajea, H. (2014), "Strategies for translating metaphorical collocations in the Holy Qur'an”, Journal of Advances in Linguistics, Vol. 4, pp. 388-396.

Al-Tabari, M. (1981),Jami' al-Bayan fi Tawil al-Qur'An, Dar al-Ma'arif, Cairo.

Al-Thaalaby, A. (1977), AL-Jawaher AL-Hisan fi Tafsir AL-Qur'an, Dar Ihya ALTurath AL-Arabi, Beirut, Lebanon.

Al-Zamakhshary, M. (1934), Al-Kashshaaf 'an Haqaa’iq Ghawaamid -it-Tanziil, Al-Mktabah alTijaariyyah al-Kubra, Cairo.

Bahumaid, S. (2006), "Collocation in English-Arabic translation”, Babel. Revue Internationale de la Traduction/International Journal of Translation, Vol. 52 No. 2, pp. 132-151, doi: 10.1075/ babel.52.2.03bah.

Baker, M. (2011), In Other Words: A Coursebook on Translation, Routledge, New York, NY.

Crystal, D. (1991), A Dictionary of Linguistics and Phonetics, Blackwell, Oxford. 
EL-Zeiny, I. (2011), "Criteria for the translation and assessment of Qur'anic metaphor", Babel. Revue Internationale de la Traduction/International Journal of Translation, Vol. 57 No. 3, pp. 247-268, doi: 10.1075/babel.57.3.01zei.

Farghal, M. and Almanna, A. (2015), Contextualizing Translation Theories: Aspects of Arabic-English Interlingual Communication, Cambridge Scholar Publishing, England.

Ghazala, H. (2004), “Translating collocations: English into Arabic”, Turjuman, Vol. 2 No. 2, pp. 7-33.

Ghazala, H. (2008), Translation as Problems and Solutions: A Course Book for University Students and Trainee Translators, Elga, Malta.

Hassan, H. and Menacere, K. (2020), “Assessing the translation quality of qur'anic collocations: for better or for worse", International Journal of Linguistics, Literature and Translation, Vol. 2 No. 2, pp. $72-79$.

Hausmann, F.J. (1989), "Le dictionnaire de collocations", in Hausmann, F., Reichmann, O., Wiegand, O. and Zgusta, L. (Eds), Wörterbücher: Ein Internationales Handbuch Zur Lexicographie, Dictionaries, Dictionnaires, De Gruyter, New York, NY, pp. 1010-1019.

Hurtado Albir, A. and Alves, F. (2009), "Translation as a cognitive activity”, in Munday, J. (Ed.), The Routledge Companion to Translation Studies, Routledge, London, pp. 54-73.

Ibn Kathir, A. (2009), Tafsir Ibn Kathir, MSA Publication Limited, United Kingdom.

Ibn Mandhur, M. (1883), Lisan AL-Arab, Al-Matb'ah al-Kubra al-'Amiriyah, Egypt.

Izwaini, S. (2016), "The translation of Arabic lexical collocations", Translation and Interpreting Studies, Vol. 11 No. 2, pp. 306-328, doi: 10.1075/tis.11.2.09izw.

Martyńska, M. (2004), “Do English language learners know collocations?”, Investigationes Linguisticae, Vol. 11 No. 1, pp. 360-371, doi: 10.14746/i1.2004.11.4.

Nassimi, D. (2008), “A thematic comparative review of some English translations of the Qur'an”, Doctoral Dissertation, University of Birmingham, Birmingham.

Newmark, P. (1988), A Textbook of Translation, Prentice Hall, London.

Obeidat, A., Ayyad, G. and Mahadi, T. (2020), "A new vision of classifying Qur'anic collocations: a syntactic and semantic perspective", E-Bangi, Vol. 17 No. 7, pp. 133-144.

Olk, H. (2013), "Cultural references in translation: a framework for quantitative translation analysis perspectives”, Perspectives, Vol. 21 No. 3, pp. 344-357, doi: 10.1080/0907676X.2011. 646279 .

Qassem, M. (2020), "Translations of stylistic variations in the Noble Qur'an into English: stylistic and exegetical perspectives", Journal of Intercultural Communication Research, pp. 1-19, doi: 10.1080/ 17475759.2020.1841016.

Qassem, M. and Gurindapalli, V. (2015), "Problematicity of translating cultural idiomatic expressions from English into Arabic", Asia Pacific Translation and Intercultural Studies, Vol. 2 No. 1, pp. 57-73, doi: 10.1080/23306343.2015.1016259.

Reiss, K. (2000), Translation Criticism: Potential and Limitations, St Jerome and American Bible Society, Manchester.

Stubbs, M. (2002), "Two quantitative methods of studying phraseology in English", International Journal of Corpus Linguistics, Vol. 7 No. 2, pp. 215-244, doi: 10.1075/ijcl.7.2.04stu.

\section{Further reading}

Al-Qurtubi, M. (1999), AL-Jameal Liahkam AL-Qur'an, Dar-A1-Fikr, Beirut, Lebanon.

Mailhac, J. (1996), "The formulation of translation strategies for cultural references", in Hoffmann, C. (Ed.), Language, Culture and Communication in Contemporary Europe, Multilingual Matters, Clevedon, pp. 132-151.

Nord, C. (2005), Text Analysis in Translation, Rodopi, Amestedam. 
PRR

5,3
Qassem, M. and Gurindapalli, V. (2019), "Culture-based text analysis in translation: a vision for comprehension", Linguistik, Vol. 95 No. 2, pp. 91-107, doi: 10.13092/lo.95.5517.

Stubbs, M. (2001b), Words and Phrases: Corpus Studies of Lexical Semantics, Blackwell, Oxford.

Stubbs, M. (1995), "Collocations and semantic profiles: on the cause of the trouble with quantitative studies", Functions of Language, Vol. 2 No. 1, pp. 23-55, doi: 10.1075/fol.2.1.03stu.

The Qur'anic Arabic Corpus-Word by word grammar "Syntax and morphology of the Holy Qur'an”, available at: http://corpus.Qur'an.com (accessed 12 May 2020).

\section{Corresponding author}

Mutahar Qassem can be contacted at: mutaharnahari@gmail.com

For instructions on how to order reprints of this article, please visit our website: www.emeraldgrouppublishing.com/licensing/reprints.htm

Or contact us for further details: permissions@emeraldinsight.com 